\title{
Some Effects of Ultrasonic Radiation on Normal Tissues
}

\author{
J. W. Cowden ${ }^{1}$ ANd M. R. Abell \\ Department of Pathology, The University of Michigan, Ann Arbor, Michigan
}

Received August 25, 1962

\section{INTRODUCTION}

Ultrasonic radiation has long been established as an important modality of physical therapy, particularly in respect to the treatment of certain neurological (Fry, 1955), circulatory (Aldes, 1957), muscular (Gersten, 1954), and arthritic disorders (Jones, 1954). Recently its use in the visualization of normal and abnormal tissues for diagnostic purposes has been explored. Wild and Reid (1953, 1954, 1955, 1957) have developed a technique for outlining tumors of breast with ultrasound, and other investigators have applied its use to the visualization of the brain (Wild and Reid, 1955), heart (Crawford et al., 1959), eye (Baum, 1960), rectum (Wild and Reid, 1957), extremities (Crawford et al., 1959), and the thorax and abdomen (Oka, 1958; Howry, 1957; Wild and Neal, 1951; Wild, 1950). Fry (W. J., 1955) and Fry (F. J., 1958) have developed the equipment and the technique for ultrasonic treatment of certain disorders of the central nervous system. The application and investigation of the effects of high intensity ultrasound on experimentally-induced neoplasms have been limited (Dimitrieva, 1960; Kikuchi et al., 1957; Schliephake, 1950; Fry, 1958a; Herrick, 1953).

The use of ultrasound in industry and science is rapidly increasing and is now applied to drilling, cleaning, polishing, sealing and grinding procedures, metallurgical flaw detection, underwater detection, emulsification, and cell breakdown. There are good indications that it may soon become the principle behind several widely used household appliances.

Thus, although ultrasonic radiation is being utilized with ever increasing frequency in the health sciences (Dussik, 1954; Zinner, 1955), engineering (Fry, 1957), research (Bell, 1958; Fry, 1958b), and industry, very little investigation of the effects of these radiations on normal tissue has been done (Lessler and Mallernee, 1958; French et al., 1951).

The basic ultrasonic unit has a generator which produces electric pulsations at a fixed frequency. The pulse is carried to the transducer, a quartz crystal, which converts the electrical energy into a mechanical vibration of the same frequency. The vibration is transferred through a coupling medium to the surface which is to be irradiated. The resulting ultrasonic waves are high frequency pressure condensations and rarefactions. They may be focused, reflected or refracted in much the same manner as light waves (Chick, 1957; Nyborg, 1957).

The following experiments were carried out to determine some of the effects of

1 Student Cancer Research Fellow, supported by USPHS CT 574. 
ultrasonic waves on normal tissues prior to their use on experimentally-induced neoplasms.

\section{MATERIALS AND METHODS}

The ultrasonic unit used throughout these experiments was the Dallons "MediSonar" Model 1000. The soundhead has a surface area of $12.5 \mathrm{sq} \mathrm{cm}$ and emits a cylindrical beam of sound waves of 1 megacycle frequency. The generator has a rated maximum output of 45 total watts but operated at a maximum of 37.5 total watts or 3 watts/sq $\mathrm{cm}$. The Dallons "Sonar-Test" meter was used to check the true output of the soundhead before and during each experiment. When tuned properly, the actual output was found to be within 1 watt of the output of the generator.

Some experiments entailed treatment under distilled water, and for this purpose a rectangular stainless steel container was used. A concave mirror (Fox and Griffing, 1949) $5 \mathrm{~cm}$ in diameter and with a focal length of $10 \mathrm{~cm}$ was used to focus the sound waves for some of the underwater treatments. The mirror and animals were positioned by use of standard laboratory stands and clamps. The following equipment was tried in an endeavor to obtain a smaller field of radiation but was rejected as being unsatisfactory for the purpose of these experiments: a convex lens of $3 \mathrm{~cm}$ focal length, a rectal extension piece for the $12.5 \mathrm{sq} \mathrm{cm}$ soundhead, and a $1 / 4 \mathrm{sq}$ inch mounted quartz crystal with a vibratory frequency of 1 megacycle.

Four experiments were carried out wherein radiation was dirccted to hepatic or testicular areas, or both. All animals were young adult male Wistar rats varying from 150 to $200 \mathrm{gm}$ in weight. The variables in the different experiments were the intensity of the ultrasonic waves, the duration of treatment, the coupling medium, cylindrical versus focused waves, and the time between treatment and death.

All rats were treated while anesthetized with $3 \mathrm{mg}$ of sodium pentobarbital per $100 \mathrm{gm}$ of weight, injected intraperitoneally. The hair was removed over the area of treatment by electric clippers followed by a chemical depilatory agent. ${ }^{2}$ For direct application of the soundhead, mineral oil was used as a coupling medium. For underwater treatment by nonfocused waves, the rat was suspended in a rubber glove with the two middle fingers cut off, permitting the testes to extend below the surface of the water while the hind legs in the index and little fingers were drawn aside, away from the direct beam. When focused sound waves were used, the rats were positioned on a pressed-wood board in which there was a hole $2 \mathrm{~cm}$ in diameter. The ultrasonic waves were directed through this hole.

\section{EXPERIMENT 1 (TABle I)}

\section{Direct application of ultrasonic irradiation}

In this experiment the ultrasonic waves were delivered to the hepatic and testicular arcas of the rat in the form of a cylindrical beam, using mineral oil as the coupling agent over each area. There were eight groups of animals that received the following: $1 \mathrm{watt} / \mathrm{sq} \mathrm{cm}$ for 1,5 , and 10 minutes; 2 watts/sq $\mathrm{cm}$ for 1,5 , and 10 minutes; and 3 watts/sq $\mathrm{cm}$ for 1 and 3 minutes.

2 Nair, manufactured by Carter Products, Inc., New York. 
TABLE I

Ultrasontc Treatment of Rat Liver and Testes

\begin{tabular}{|c|c|c|c|c|c|}
\hline $\begin{array}{r}I \\
\text { Grou }\end{array}$ & $\begin{array}{l}\text { ntensity of } \\
\text { p sound waves }\end{array}$ & $\begin{array}{l}\text { Duration } \\
\text { of } \\
\text { treatment }\end{array}$ & $\begin{array}{c}\text { Number } \\
\text { of } \\
\text { animals }\end{array}$ & Signi & ant pathologic visceral lesions \\
\hline 1 & $1 \mathrm{watt} / \mathrm{sq} \mathrm{cm}$ & 1 minute & $\mathrm{XXX}$ & None & \\
\hline 2 & $1 \mathrm{watt} / \mathrm{sq} \mathrm{cm}$ & 5 minutes & $\mathrm{XXX}$ & $\begin{array}{l}\text { Liver (1) } \\
\text { Testes (3) } \\
\text { Kidney (1) } \\
\text { Intestine (1) }\end{array}$ & $\begin{array}{l}\text { Congestion, necrosis } \\
\text { Fragmentation, degeneration, necrosis } \\
\text { Congestion } \\
\text { Congestion }\end{array}$ \\
\hline 3 & $1 \mathrm{watt} / \mathrm{sq} \mathrm{cm}$ & 10 minutes & 000 & $\begin{array}{l}\text { Liver (3) } \\
\text { Testes (3) } \\
\text { Kidney (3) } \\
\text { Intestine (3) }\end{array}$ & $\begin{array}{l}\text { Congestion } \\
\text { Degeneration, fragmentation } \\
\text { Hyaline droplet degeneration } \\
\text { Hemorrhage, necrosis }\end{array}$ \\
\hline 4 & $2 \mathrm{watts} / \mathrm{sq} \mathrm{cm}$ & 1 minute & $\mathrm{XXX}$ & None & \\
\hline 5 & 2 watts $/ \mathrm{sq} \mathrm{cm}$ & 5 minutes & 0000 & $\begin{array}{l}\text { Liver (4) } \\
\text { Testes (4) } \\
\text { Kidney (1) } \\
\text { Intestine (3) }\end{array}$ & $\begin{array}{l}\text { Necrosis } \\
\text { Fragmentation, congestion } \\
\text { Congestion } \\
\text { Hemorrhage, necrosis }\end{array}$ \\
\hline 6 & 2 watts $/ \mathrm{sq} \mathrm{cm}$ & 10 minutes & 000 & $\begin{array}{l}\text { Liver (3) } \\
\text { Testes (3) } \\
\text { Kidney (2) } \\
\text { Intestine (2) }\end{array}$ & $\begin{array}{l}\text { Necrosis } \\
\text { Fragmentation } \\
\text { Hyaline droplet degeneration } \\
\text { Hemorrhage, necrosis }\end{array}$ \\
\hline 7 & 3 watts $/ \mathrm{sq} \mathrm{cm}$ & 1 minute & $\mathrm{XXX}$ & Testes (3) & Fragmentation, congestion \\
\hline 8 & $3 \mathrm{watts} / \mathrm{sq} \mathrm{cm}$ & 3 minutes & $\mathrm{XXO}$ & $\begin{array}{l}\text { Liver (3) } \\
\text { Testes (3) } \\
\text { Kidney (1) } \\
\text { Intestine (3) }\end{array}$ & $\begin{array}{l}\text { Degeneration } \\
\text { Fragmentation, degeneration } \\
\text { Hyaline droplet degeneration } \\
\text { Inflammation, necrosis }\end{array}$ \\
\hline
\end{tabular}

a $\mathrm{X}=$ Sacrificed after 24 hours; $\mathrm{O}=$ died 4-22 hours after treatment.

\section{EXPERIMENT 2 (TABLE II)}

\section{Under water application of ultrasonic irradiation}

The ultrasonic treatment of these groups was directed to the testes only in the form of a cylindrical beam underwater and at an intensity of 3 watts $/ \mathrm{sq} \mathrm{cm}$ for 5,10 , and 15 minutes. Surviving animals were sacrificed at the end of 3 weeks, except for one animal in group 2 which was sacrificed carlier because of severe illness.

\section{EXPERIMENT 3 (TABLE III)}

\section{Focused ultrasonic irradiation}

All animals in this experiment were treated over areas of liver and testes with focused sound waves at an intensity of 37.5 total watts for periods of 5 and 10 minutes. The intensity of 37.5 total watts is equivalent to an output of 3 watts $/ \mathrm{sq} \mathrm{cm}$ at the surface of the soundhead. Focal distances from the reflecting mirror to the skin over the hepatic and testicular areas were 7 and $8 \mathrm{~cm}$ respectively. Surviving animals were sacrificed at various periods from immediately after treatment to 3 days after treatment. 
TABLE II

Rat Testes Treated with 3 watts SQ CM UNDER Water

\begin{tabular}{|c|c|c|c|c|c|}
\hline Group & $\begin{array}{c}\text { Duration of } \\
\text { treatment }\end{array}$ & $\begin{array}{l}\text { Number of } \\
\text { animals }^{a}\end{array}$ & $\begin{array}{l}\text { Survival } \\
\text { time }\end{array}$ & \multicolumn{2}{|c|}{ Significant visceral pathologic lesions } \\
\hline \multirow[t]{4}{*}{1} & 5 minutes & 000 & 2 days & Testes (3) & Necrosis, fragmentation \\
\hline & & & & Epididymis (3) & Necrosis, fragmentation \\
\hline & & $\mathrm{XXX}$ & 21 days & Testes (3) & Fragmentation \\
\hline & & & & Epididymis (2) & $\begin{array}{l}\text { Ruptured tubules, } \\
\text { Epithelioid response }\end{array}$ \\
\hline \multirow[t]{4}{*}{2} & 10 minutes & 000 & 1 day & Testes (3) & Fragmentation, necrosis \\
\hline & & & & Epididymis (3) & Hemorrhage, degeneration \\
\hline & & $\mathbf{X}$ & 4 days & Testes (1) & Fragmentation, degeneration \\
\hline & & & & Epididymis (1) & Hemorrhage, degencration \\
\hline \multirow[t]{6}{*}{3} & 15 minutes & $\mathrm{O}$ & 12 hours & Testes (1) & Fragmentation, congestion \\
\hline & & & & Epididymis (1) & Hemorrhage, degeneration \\
\hline & & 0000 & $1-4$ days & Testes (4) & Fragmentation, necrosis \\
\hline & & & & Epididymis (2) & Necrosis, fragmentation \\
\hline & & $\mathbf{X}$ & 24 days & Testes (1) & Calcified necrosis \\
\hline & & & & Epididymis (1) & Chronic inflammation \\
\hline
\end{tabular}

$a \mathrm{X}=$ Sacrificed $\mathrm{O}=$ died.

TABLE III

Rat Liver and Testes Treated with 37.5 watts Focused Underwater

\begin{tabular}{|c|c|c|c|c|c|}
\hline Group & $\begin{array}{l}\text { Duration of } \\
\text { treatment }\end{array}$ & $\begin{array}{l}\text { Number of } \\
\text { animals }\end{array}$ & $\begin{array}{l}\text { Survival } \\
\text { time }\end{array}$ & \multicolumn{2}{|c|}{ Significant pathologic visceral lesions } \\
\hline \multirow[t]{3}{*}{1} & 5 minutes & $\mathrm{XXX}$ & 5 minutes & $\begin{array}{l}\text { Liver (2) } \\
\text { Testes (3) } \\
\text { Intestine (2) }\end{array}$ & $\begin{array}{l}\text { Early necrosis, hemorrhage } \\
\text { Fragmentation } \\
\text { Hemorrhage }\end{array}$ \\
\hline & & OO & 6,12 hours & $\begin{array}{l}\text { Liver (2) } \\
\text { Testes (2) } \\
\text { Intestine (1) }\end{array}$ & $\begin{array}{l}\text { Congestion, degeneration } \\
\text { Fragmentation } \\
\text { Hemorrhage, necrosis }\end{array}$ \\
\hline & & $\mathrm{XXXXXX}$ & $2-4$ days & $\begin{array}{l}\text { Liver (3) } \\
\text { Testes (4) } \\
\text { Intestine (1) }\end{array}$ & $\begin{array}{l}\text { Focal necrosis } \\
\text { Fragmentation } \\
\text { Necrosis }\end{array}$ \\
\hline 2 & 10 minutes & OOX & $3-24$ hours & $\begin{array}{l}\text { Liver (2) } \\
\text { Testes (3) } \\
\text { Intestine (1) } \\
\text { Kidney (2) }\end{array}$ & $\begin{array}{l}\text { Early necrosis } \\
\text { Congestion, fragmentation } \\
\text { Hemorrhage, necrosis } \\
\text { Hyaline droplet degeneration }\end{array}$ \\
\hline
\end{tabular}

$a \mathrm{X}=$ Sacrificed $; \mathrm{O}=$ died.

\section{EXPERIMENT 4}

\section{Ultrasonic irradiation of livers after death}

Livers in situ in normal sacrificed animals and livers removed immediately after sacrifice were treated with focused sound waves of an intensity of 37.5 total watts. Portions of human livers removed at necropsy were also treated with the same intensity. The duration of treatments varied from 5 seconds to 5 minutes.

Necropsies were performed as soon as possible on all animals that died during the course of the experiments and on those that were sacrified after specific periods. 
Sections of liver, kidney, testis, skin, intestine, tail, muscle, and pelvic bones were examined. The tissues were fixed in $10 \%$ formalin, and hematoxylin and eosin-stained sections were prepared. Fat stains, Sudan IV, were done on all livers of Experiment 4.

\section{RESULTS}

\section{EXPERIMENT 1 (TABLe I)}

\section{Direct application of ultrasonic irradiation}

The rats treated with 1 watt/sq $\mathrm{cm}$ for 10 minutes and 2 watts $/ \mathrm{sq} \mathrm{cm}$ for 5 and 10 minutes died within 24 hours. One animal treated with 3 watts $/ \mathrm{sq} \mathrm{cm}$ for 3 minutes also died within the 24 hour period.

All rats had cutaneous lesions after treatment. Progressively more severe skin damage was notcd as the intensity and duration of the treatments werc increased. The lesions ranged from small, slightly brown blisters to large, reddish-brown, firm indurated plaques up to $3 \mathrm{~cm}$ in diameter with edematous and erythematous margins. The scrotums were dark, very congested, and swollen.

No significant visceral lesions were observed in the animals treated with 1 watt and 2 watts/sq $\mathrm{cm}$ for 1 minute (Table I). In the majority of the remaining animals treated, gross lesions were present; these were more apparent in animals that received treatment at high intensity and long duration. In such animals the testes were congested and swollen, the urinary bladder hemorrhagic, the kidneys congested, especially the right, and the abdominal wall and scrotum were discolored and hemorrhagic. Areas of hepatic necrosis were not clearly defined on gross inspection as they were in Experiment III when treated with focused ultrasound, but could be detected in some instances as mottled, pale and hemorrhagic foci.

Histologic examinations disclosed varying degrees of congestion, edema, degeneration, necrosis; and inflammation in skin and subcutaneum, skeletal muscle, liver, testis, epididymis, kidney and intestine (Table I). The areas in liver represented simple and coagulation necrosis with hemorrhage. There was some leukocytic infiltrate near the periphery of the necrotic foci. The earliest changes were minimal and consisted of alteration in staining reaction and some karyolysis and karyorrhexis.

The areas of necrosis in testis were superficial and either crescent- or wedge-shaped beneath the capsule. In these areas there was loss of cellular detail but no significant inflammation. Around the areas of necrosis and in less aggressively treated animals were zones of degeneration and fragmentation of germinal and tubular supporting cells, congestion, and edema (Fig. 1). The epididymis reflected to some extent the testicular changes; the lumens were filled with castoff germinal cells, cellular debris, and desquamated epithelial cells from the tubules (Fig. 2).

The right kidney was generally included, in part at least, in the field of irradiation; in rats of groups 3,6 , and 8 there were areas of hyaline droplet degeneration in the form of bright eosinophilic cytoplasmic droplets in cells of the proximal convoluted tubules. This change was not uniform throughout the entire kidney and corresponded to mottled pale and congested areas detected in the gross examination. Hyaline droplet degeneration was not observed in the left kidney.

Acute congestion, focal hemorrhage and necrosis of mucosa, submucosa and sometimes muscularis were found in the intestines of groups 3,5, 6, and 8. Severe in- 


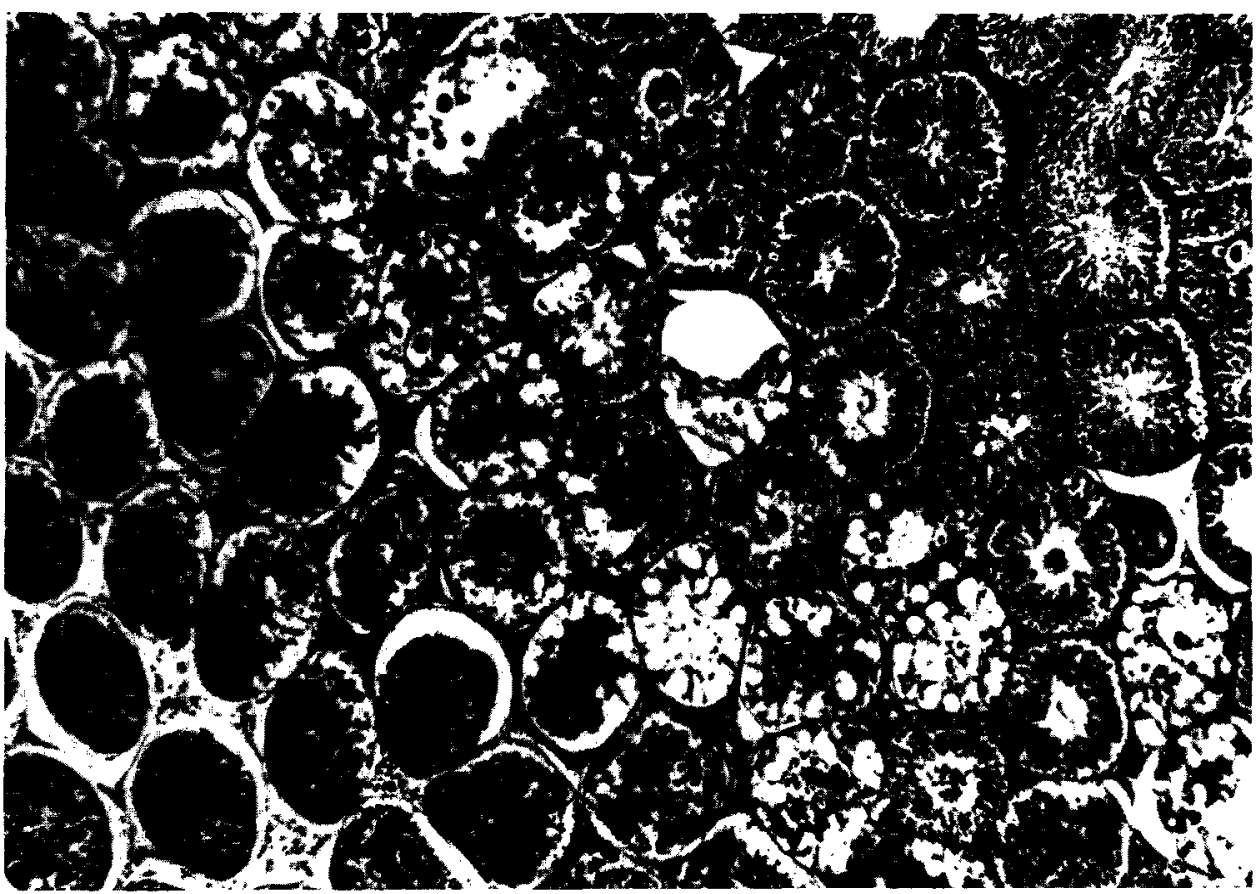

FIG. 1. Testis, 24 hours after direct irradiation for 5 minutes with 1 watt $/ \mathrm{sq} \mathrm{cm}$ of ultrasound. A band of vacuolar degeneration with giant cell formation separates the necrotic tissue in left lower area from normal testis in right upper area. Hematoxylin-cosin, $\times 65$.

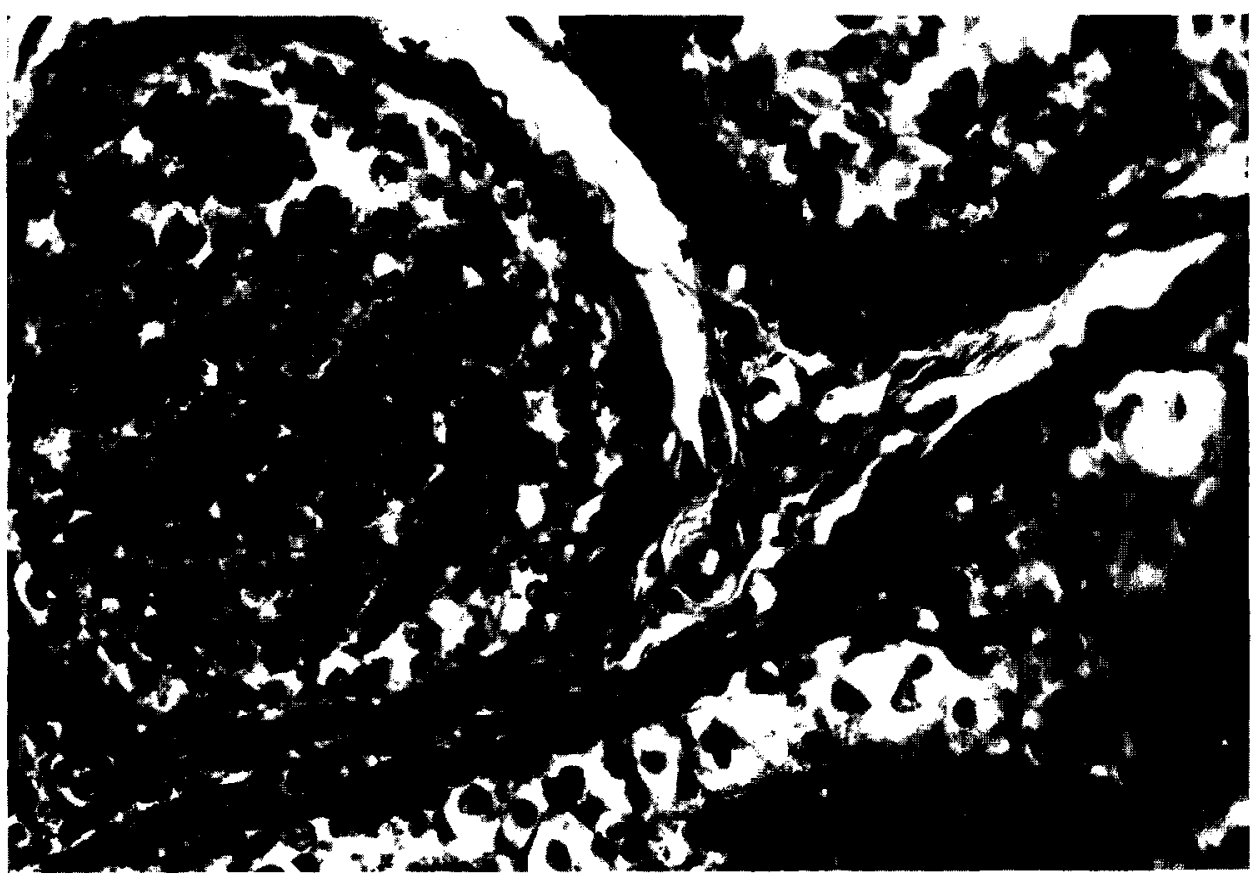

FIG. 2. Lumen of epididymis filled with cast-off germ cells and cellular debris; vacuolation and necrosis of lining epithelium. This is 24 hours after treatment for 5 minutes with 1 watt $/ \mathrm{sq} \mathrm{cm}$ of direct ultrasound. Hematoxylin-eosin, $\times 370$. 
flammation and edema often accompanied the formation of necrotic mucosal ulcers (Fig. 3).

In the irradiated areas there was necrosis of skeletal muscle, indicated by altered staining reaction of fibers and loss of sarcolemmal nuclei. Focal collections of inflammatory cells and hemorrhage were scattered throughout the damaged muscle.

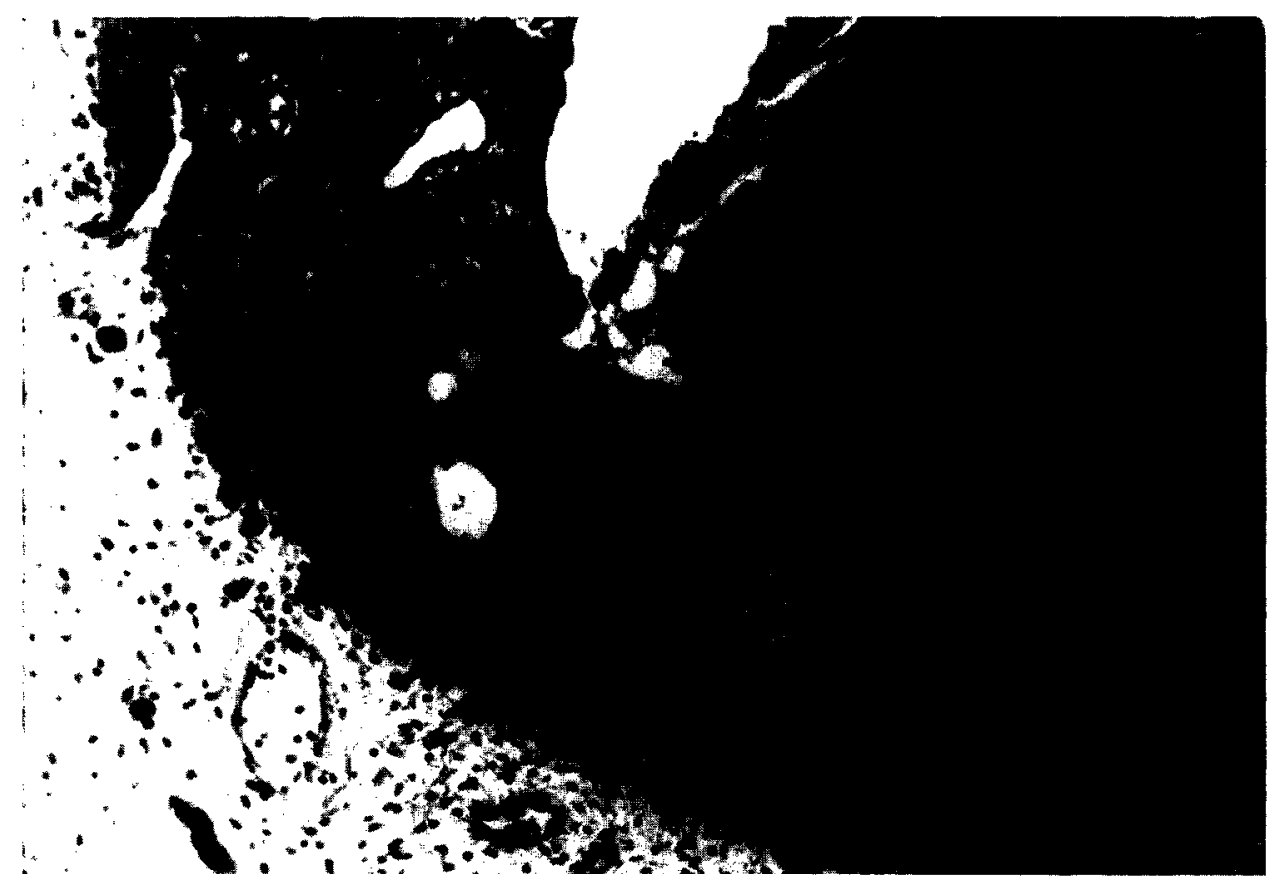

FIG. 3. Necrosis and ulceration of colonic mucosa with the formation of a plaque of fibrin, blood, necrotic debris, and exudate. The animal was sacrificed 24 hours after direct treatment with $1 \mathrm{watt} / \mathrm{sq} \mathrm{cm}$ of ultrasound for 5 minutes. Hematoxylin-eosin, $\times 45$.

The epidermis in the treated areas had a coagulated appearance with loss of cell detail. The dermis was extremely edematous, congested, and sometimes hemorrhagic. Inflammatory reaction was mainly perivascular and variable in intensity.

\section{Experiment 2 (Table II)}

\section{Underwater application of ultrasonic irradiation}

The majority of the animals in this experiment developed diarrhea and paralysis, generally temporary, of the hind limbs. The skin of the scrotum and over the lower region of the back near the base of the tail was quite warm after treatment and became indurated, congested, and brown in color. Necrosis often appeared at the base of the tail and the animals sometimes gnawed at this area, resulting in separation of tails. In five animals at necropsy the tails were attached by skin alone, the underlying tissues being necrotic. The urinary bladder was usually distended in animals that died and contained hemorrhagic urine. The four rats in groups 1 and 3 that survived were mated with young mature females but no offspring resulted.

Testicular changes of some degree were present in all animals and ranged from degeneration and fragmentation to areas of definite necrosis (Table II). 


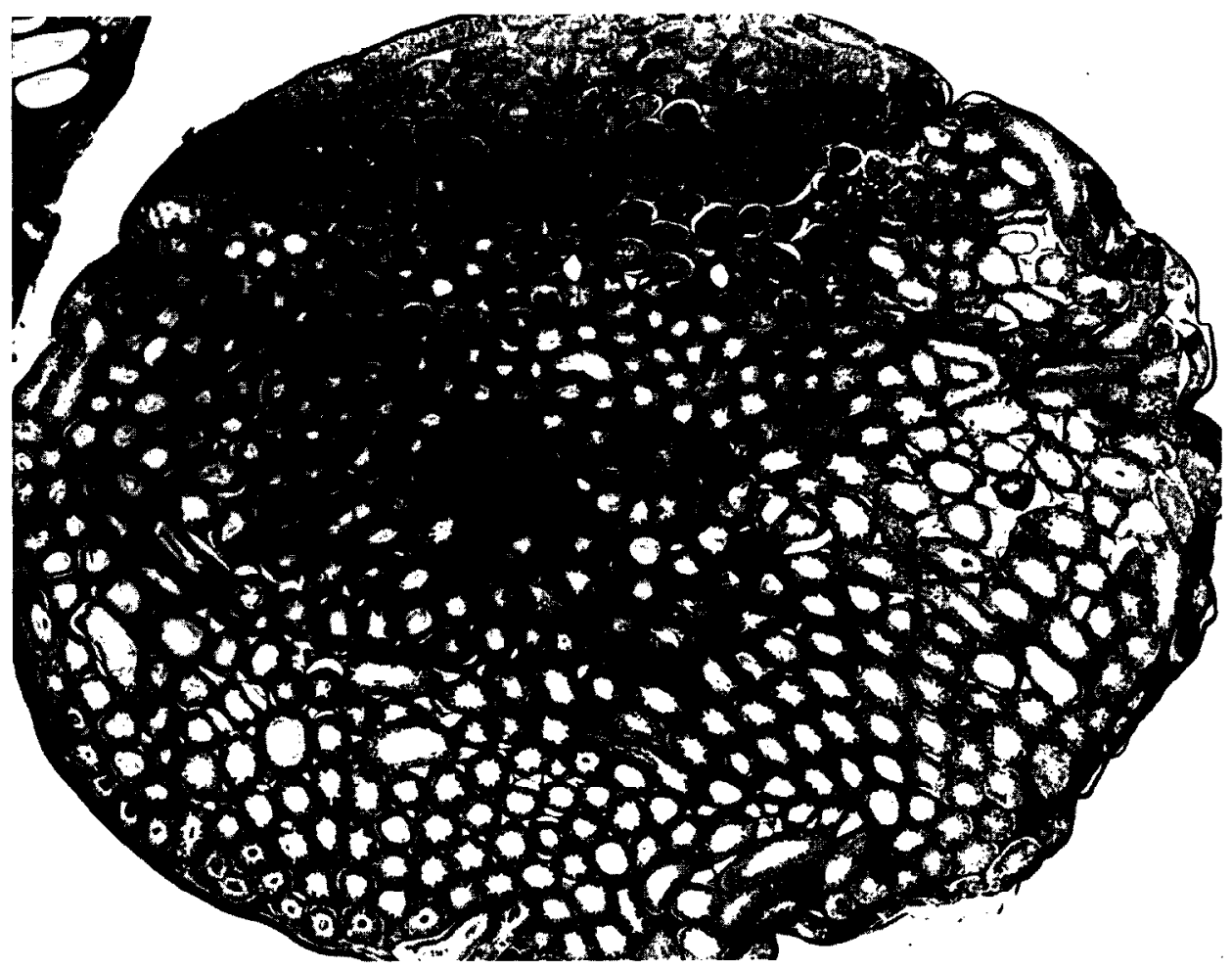

FIG. 4. Necrotic area beneath the capsule of testis 48 hours after 5 minutes of ultrasonic irradiation underwater, 3 watts $/ \mathrm{sq} \mathrm{cm}$. Hematoxylin-eosin, $\times 15$.

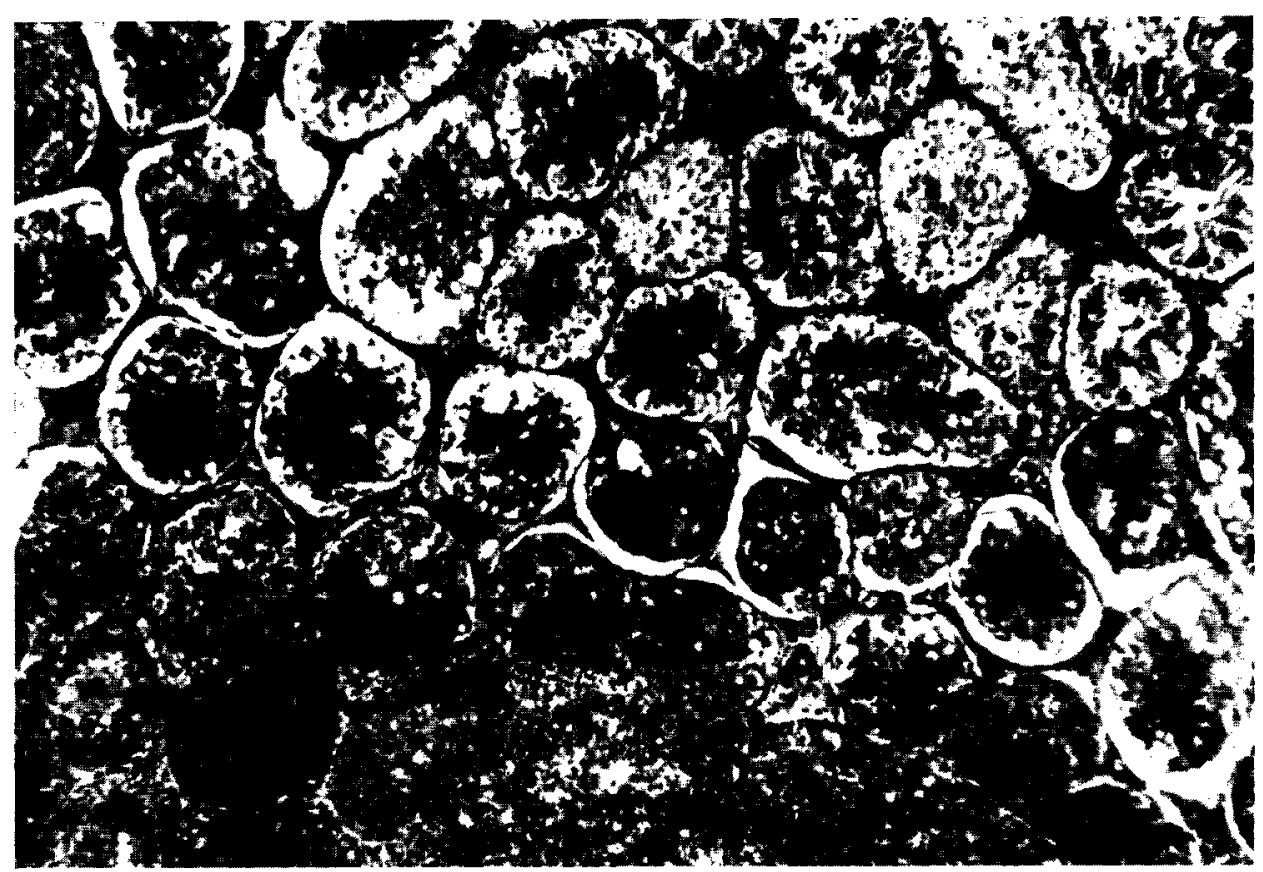

FIG. 5. Extensive necrosis (lower portion) and degeneration of testis 96 hours after 15 minutes of ultrasonic irradiation underwater at 3 watts $/ \mathrm{sq} \mathrm{cm}$. Hematoxylin-eosin, $\times 65$. 


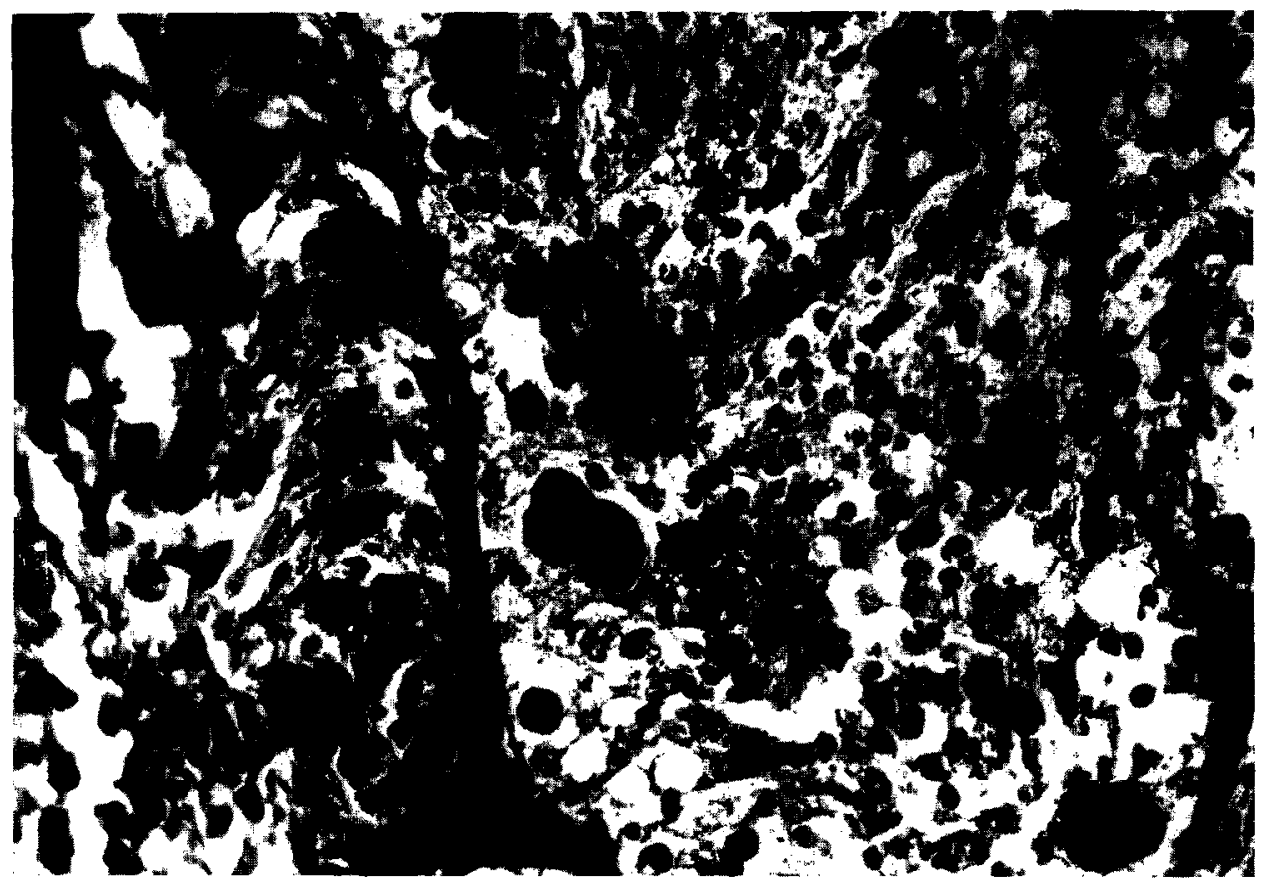

FIG. 6. Advanced tubular degeneration and giant cell formation 96 hours after 15 minutes of 3 watts/sq $\mathrm{cm}$ of ultrasound delivered underwater. Hematoxylin-ecsin, $\times 250$.

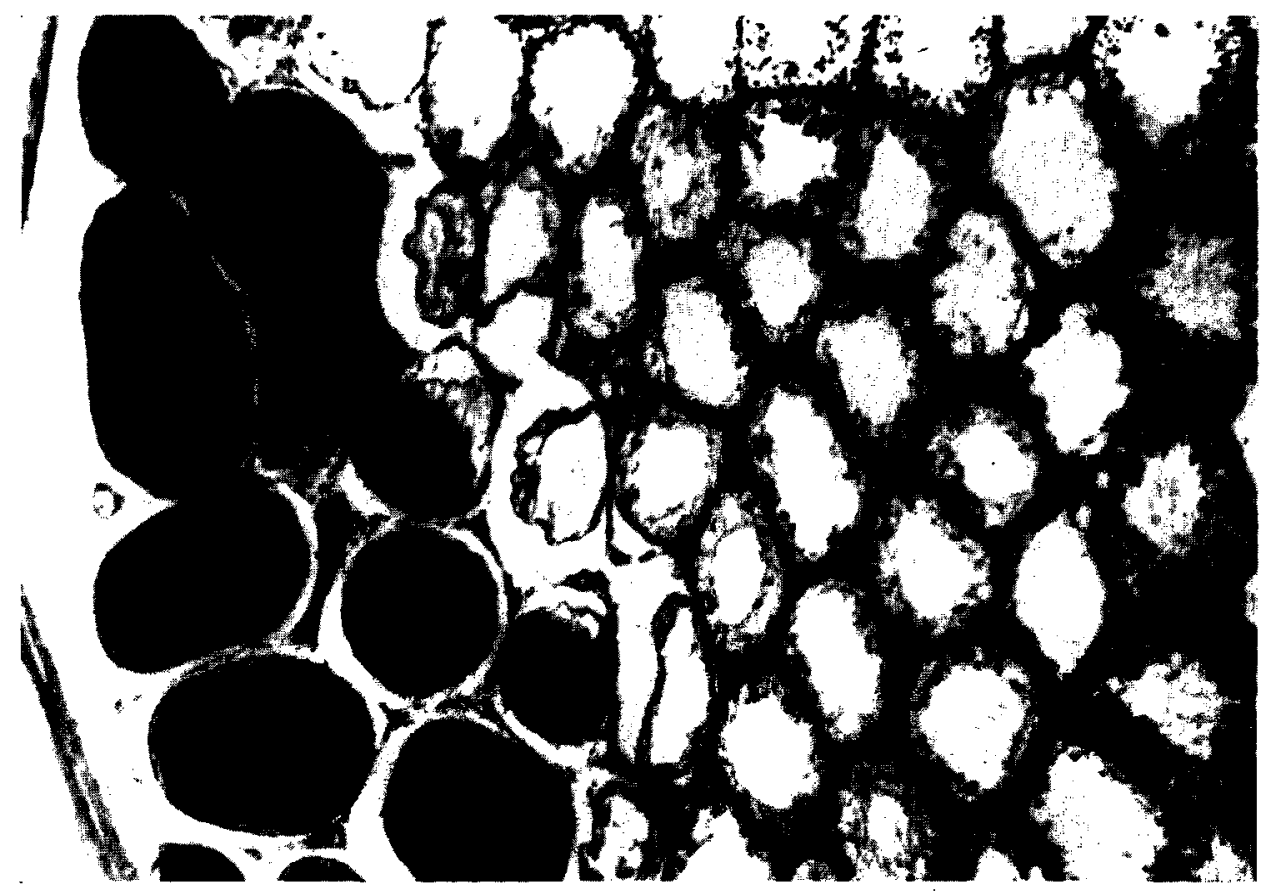

Fig. 7. An area of old necrosis of seminiferous tubules with dystrophic calcification at right. In the center of the field there is a loss of germ cells and atrophy of tubules. Towards the left, a few of the tubules approach a normal appearance. This animal was sacrificed 24 days after it was treated with 3 watts $/ \mathrm{sq} \mathrm{cm}$ of ultrasound underwater. Hematoxylin-eosin, $\times 100$. 


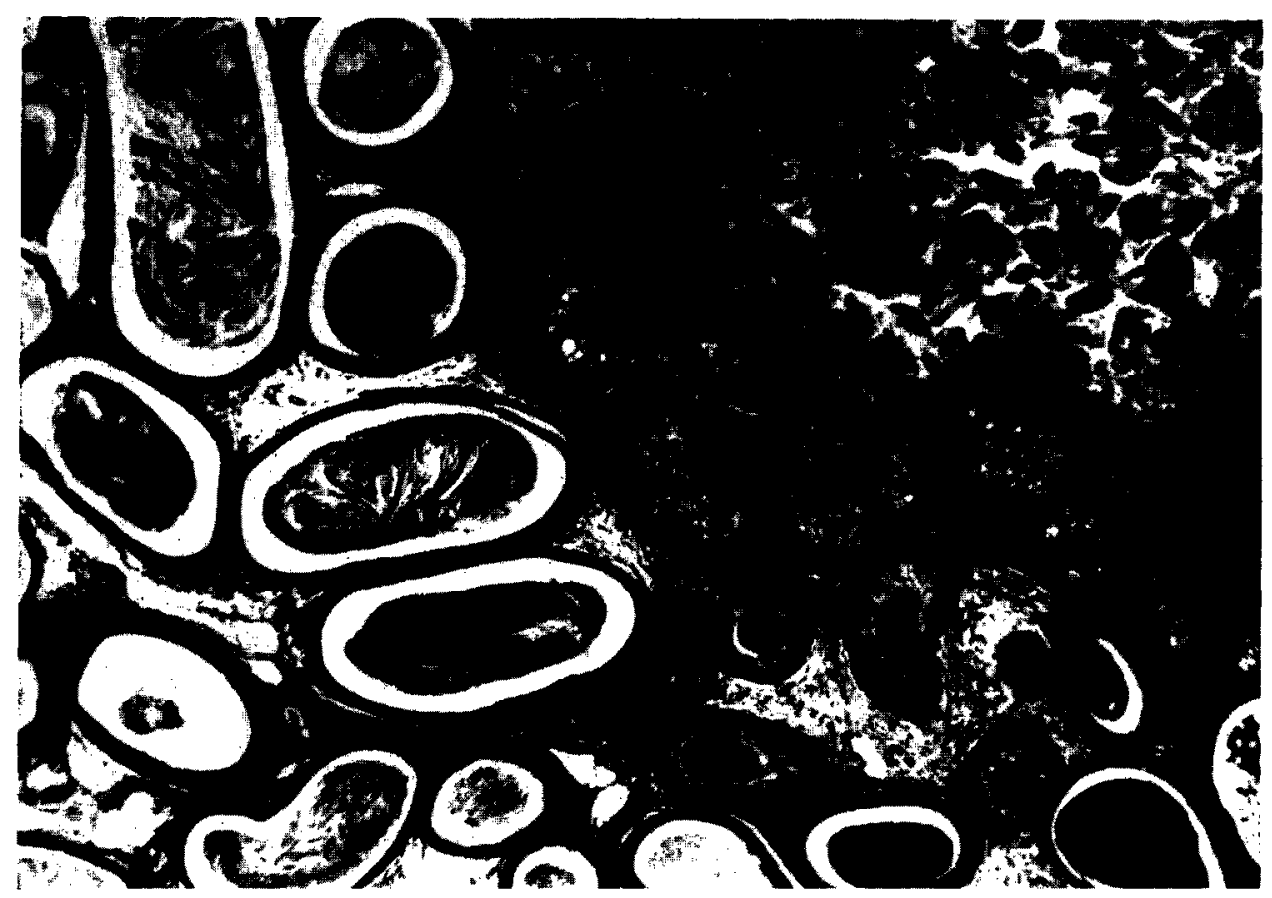

FIG. 8, Ruptured epididymal tubule with a surrounding epithelioid response to the necrotic debris 96 hours after treatment for 15 minutes with 3 watts $/ \mathrm{sq} \mathrm{cm}$ of ultrasound underwater. Hematoxylin-eosin, $\times 180$.

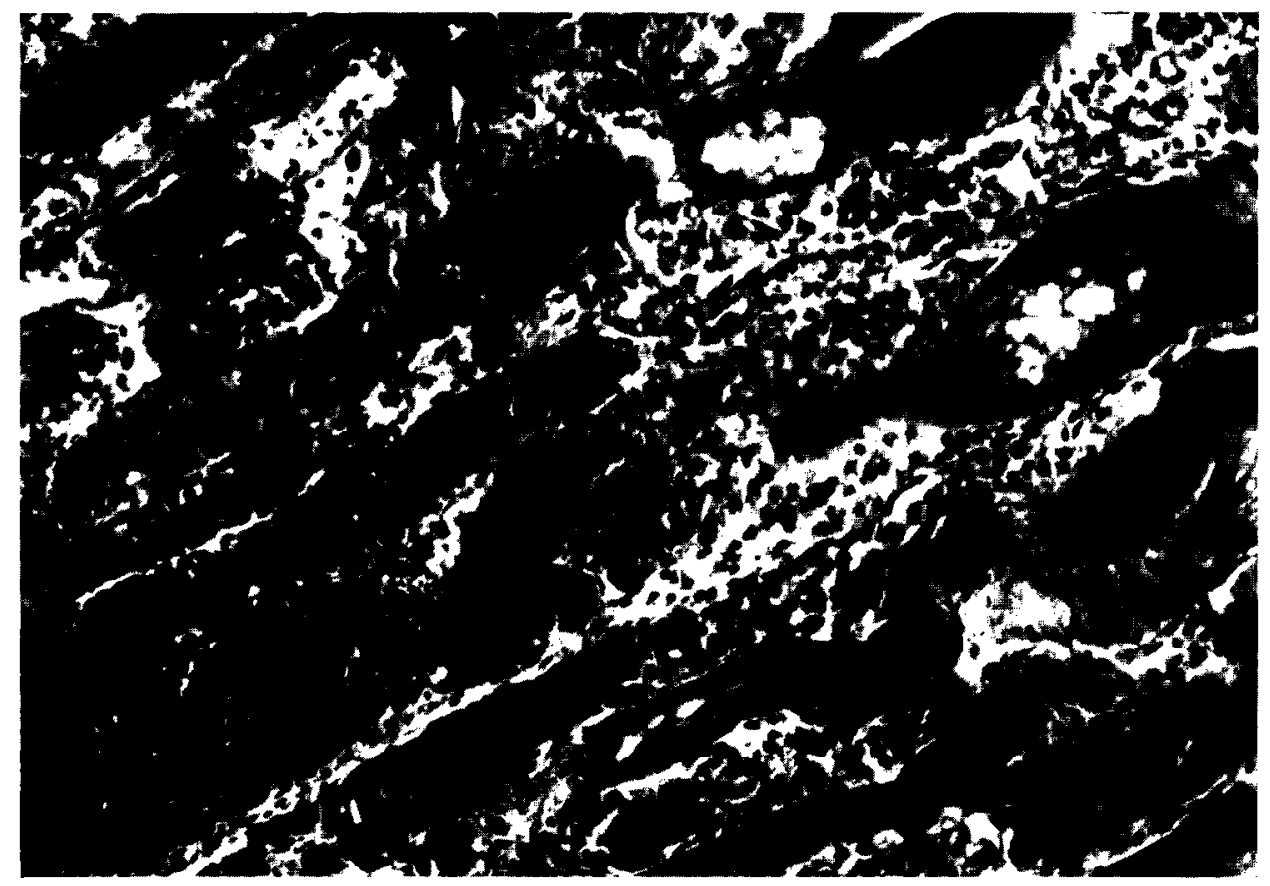

FIG. 9. Vacuolar degeneration, necrosis, inflammation and dystrophic calcification of muscle 96 hours after 15 minutes of ultrasonic irradiation underwater at 3 watts $/ \mathrm{sq} \mathrm{cm}$. Hematoxylin-eosin, $\times 185$. 
The areas of necrosis were located along one surface and extended about onequarter of the distance through the testis in a conical configuration (Figs. 4 and 5). The interstitial spaces were congested, edematous, and filled with leukocytes. The germinal and Sertoli cells of tubules were necrotic and fragmented, and the lumina were filled with necrotic debris. In the degenerative region surrounding the necrotic area, the tubular cells were vacuolated and multinucleated giant cells were present (Figs. 5 and 6). The cytoplasm of the giant cells was deeply stained and homogeneous; the nuclei were small, uniform, and hypcrchromatic. One rat sacrificed after 24 days and examined grossly had a hard, white lesion on the surface of the left testis. The area proved to be old necrosis with dystrophic calcification of seminiferous tubules (Fig. 7).

The epididymides were markedly affected in nearly all instances, being congested and hemorrhagic, with areas of degeneration and necrosis. In a number of cases the lumina contained strips of epithelial cells with numerous degenerated and necrotic germ cells. In two animals the tubules had ruptured, forming pseudocysts filled with cellular debris from the testis and epididymis (Fig. 8). There was a prominent epithelioid and inflammatory response with some fibrosis to this material. Dilatation and degeneration of the distal convoluted tubules of the kidneys were found in most cases where the urinary bladder was extremely full and may have been due to paralytic obstruction.

Skeletal muscle in cross sections through the lower pelvis was degenerated and necrotic with a severe inflammatory reaction, vacuolation, and dystrophic calcification (Fig. 9). In this group, necrosis of the bone, muscle, and skin of the tail was common; there was also thrombosis of blood vessels and moderate inflammatory response.

\section{EXPERIMENT 3 (TABLE III)}

\section{Focused ultrasonic irradiation}

The outstanding lesions produced by focused ultrasound were in the liver. Grossly, the lesions appeared on the surface after an interval of 2 days as localized pale yellow or white sharply defined areas approximately $1 \mathrm{~cm}$ in diameter (Fig. 10). Prior to 2 days after treatment, the area of damage could be detected by altered color and focal hemorrhage. Histologically there was complete necrosis with a surrounding inflammatory reaction in animals which lived a day or more. Immediately after irradiation there were congestion and petechial hemorrhages. Three hours after treatment early coagulation necrosis with slight leukocytic invasion, karyolysis, karyorrhexis, and congestion at the edge of the lesion was evident (Fig. 11). The necrosis and inflammation progressed up to 2 days. There was disappearance of nuclei in the necrotic areas, increased leukocytic infiltrate, and a border zone of leukocytes and early fibrosis (Fig. 12). After 2 days the inflammatory reaction decreased. A well-defined border of fibrous reaction separated the necrotic from the normal tissue after 4 days.

The testes were not necrotic, but most had a fragmentation of the normally compact tubular structure. The intestinal tract was especially susceptible to focused ultrasound. Large hemorrhagic and ulcerated areas were common. Inflammation, necrosis, edema, and hemorrhage were usually found in the lower colon after intense 

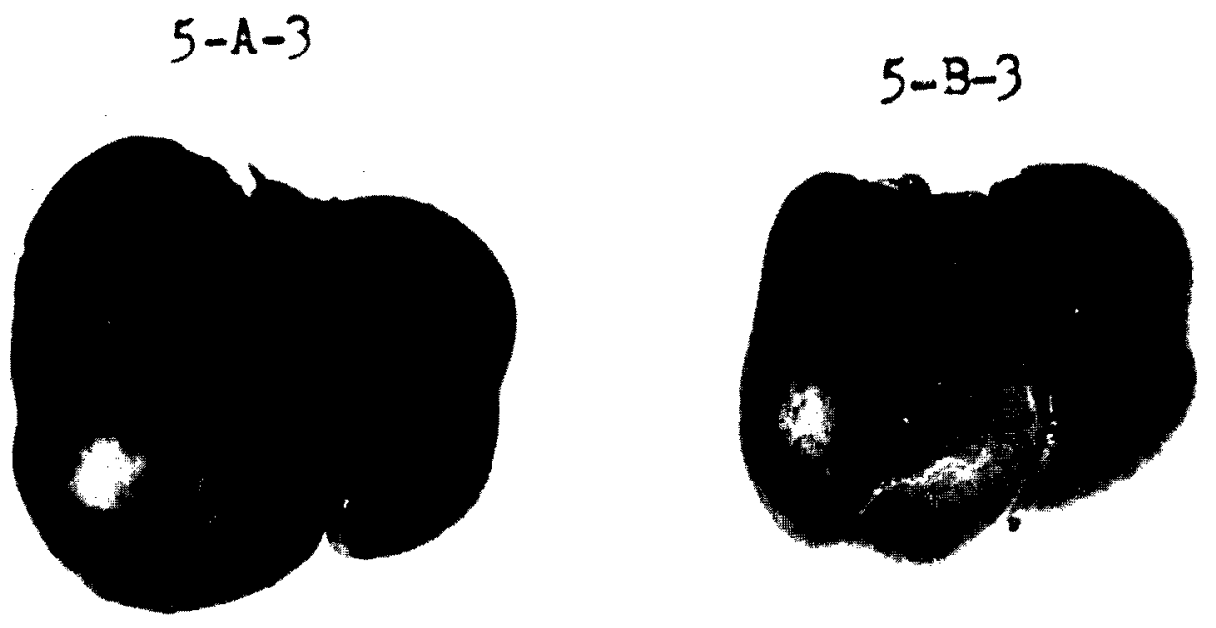

FIG. 10. Gross appearance of lesions in liver 24 hours after 37.5 watts of ultrasound focused underwater for 5 minutes. The circular light areas on the surfaces with thin peripheries of dark congestion represent the necrosis.

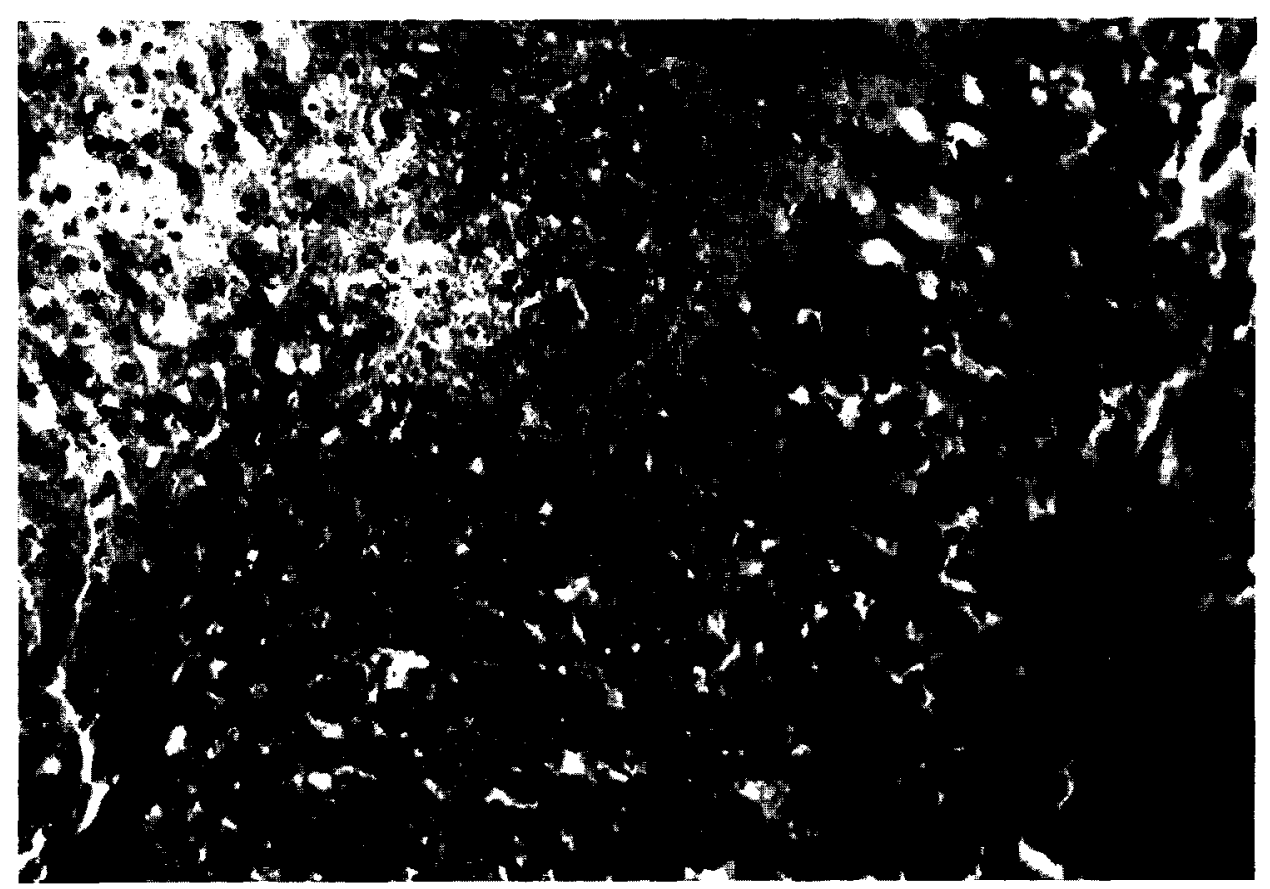

FIG. 11. An area of early coagulation necrosis of liver with congestion of surrounding liver. The necrotic cells are pale, with pyknotic nuclei and in some areas complete loss of nuclei. This is 3 hours after treatment with 37.5 walts of fucused ultrasound underwater for 5 minutes. Hematoxylin-eosin, $\times 190$. 
treatment of the testes. Several rats had hyaline droplet degeneration in the proximal convoluted tubules of the right kidney and other degenerative changes. The skin from the abdominal wall and scrotum was congested and edematous, but the extent of the lesions was less than that produced by the direct application of the soundhead.

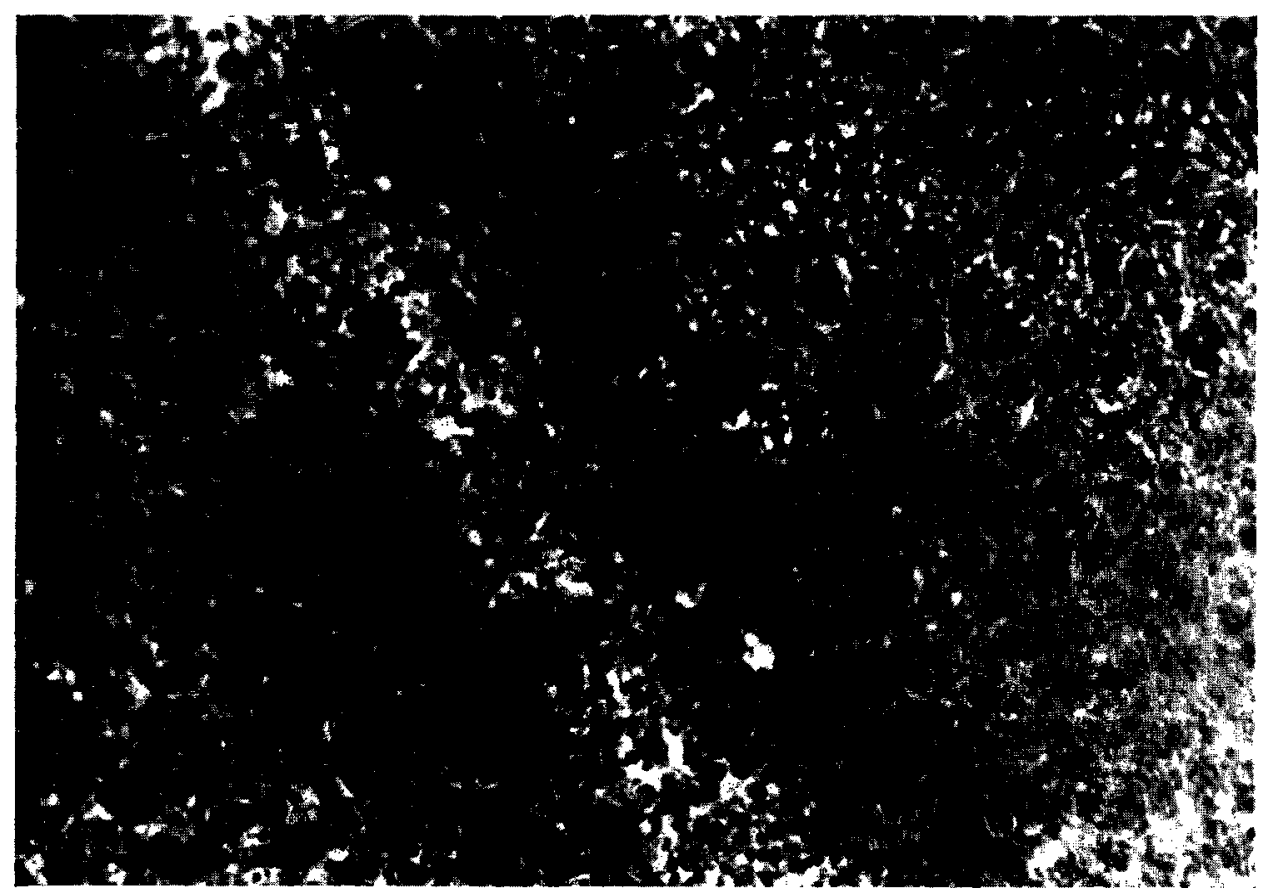

Fic. 12. A well-defined necrotic area in liver (left) with a peripheral inflammatory and fibrotic zone separating it from normal liver. The animal was sacrified 48 hours after 5 minutes of treatment underwater with focused ultrasound. Hematoxylin-eosin, $\times 170$.

\section{EXPERIMENT 4}

\section{Ultrasonic irradiation of livers after death}

Grossly, the lesions were pale, penetrating to $4 \mathrm{~cm}$ in a block of liver tissue with a conical shape. It took only 5 seconds of irradiation before discoloration began to appear on the opposite side of a $1 \mathrm{~cm}$ slice of liver. The discoloration increased until about 1 minute, but no additional change was noted with 5 minutes of irradiation. The degree of paleness was most prominent at the surface nearest the mirror. Eight slices of liver, $0.5 \mathrm{~cm}$ each in thickness, were placed together and treated for $3 \mathrm{~min}$ utes. The lesion extended through all the sections. At each interface the area of paleness was greater in diameter than that inside the section of liver through which the beam passed. However, as the distance between the mirror and interface increased, the diameter of the lesion decreased. The pale area immediately after treatment was warm while the rest of the block was about room temperature. The longer the treatment, the warmer the lesion became.

Microscopically, all of the lesions in general appeared the same. The major change was cavitation, consisting of bubble formation in the extracellular spaces. Some fine 
intracellular cavitation may also have been present. These areas did not contain lipid in Sudan IV stains. Cavitation of livers was not observed in living animals but only in livers of dead animals or in livers removed and treated.

Some of the cavities contained debris which suggested the possibility that the process could have arisen intracellularly and destroyed the cell. The cells surrounding the cavity appeared compressed.

\section{DISCUSSION}

Ultrasound has three types of action on tissues: thermal, mechanical, and chemical (Schliephake, 1950; Kobak, 1954). The increase in temperature is due to the absorption of the energy of the mechanical waves by the tissues at the various interfaces through which the sound passes (Bauer, 1951; Carstensen, 1960). Lehmann (1953a) stated that the selective heating effect at interfaces disappeared with lower intensities. Effects such as micromassage, according to Jankowiak et al. (1958), play an important role at therapeutic doses. Ultrasonic "stirring" at the interface augments the exchange of metabolites by decreasing the diffusion layer (Lehmann, 1953a). Increased permeability of capillaries and cell membranes may be attributed to the ultrasonic "stirring" or to an increase in the pore size (Baldes et al, 1958). Cavitation, considered to be due to gas bubble formation, does not take place in vivo at therapeutic doses (Lehmann, 1953b), nor was it produced in vivo with intensities used in this experiment. Some investigators believe that enzyme systems may be broken down or blocked due to molecular changes (Baldes et al., 1958). Others claim that there is an acceleration of oxidation and other chemical reactions (Schliephake, $1950)$. The action of intense ultrasound of $500-1000$ watts $/ \mathrm{sq} \mathrm{cm}$ on tissues has effects different from that of low intensity irradiation (Dunn, 1958).

The major problems to be solved by experimentation were the maximum sublethal dose (dosage involves intensity and duration of treatment), the minimum effective dose to produce pathological effects, the length of time after treatment at which the pathological alterations are optimum, and the manner of focusing ultrasound to produce a localized lesion.

The maximum sublethal dose for rats of 150-200 gm with direct application as determined in the first series of tests was 1 watt/sq $\mathrm{cm}$ for 5 minutes; 2 watts/sq $\mathrm{cm}$ for 3 minutes, and 3 watts $/ \mathrm{sq} \mathrm{cm}$ for 1 minute. Underwater application increased the maximum sublethal dose to 3 watts/sq $\mathrm{cm}$ for 5 minutes. By using a concave mirror underwater to focus the soundwaves, a small lesion was readily produced, usually without killing the animal. There was difficulty in producing the lesion in the exact spot desired; more precise equipment is needed for this purpose (Fry, F. J., 1958; Fry, W. J., 1958b; Hueter, 1958; Lynn et al., 1942).

Pathological lesions were noted in nearly every rat that died following treatment; however, several rats died within the first 24 hours and no significant lesions were found. Septicemia following damage to the gastrointestinal tract may have caused irreversible bacterial shock in some animals.

The most effective method to produce a lesion in the liver was the focused ultrasound for 5 minutes or longer using 37.5 total watts. No other intensity was tried.

Statements have been made to the effect that liver cells cannot be destroyed by even the largest amount of ultrasonic energy (Schliephake, 1950); these obviously 
must refer to the output of the equipment which was available because, as shown by these experiments, the liver as well as other tissues can be markedly affected by the use of large doses from a therapeutic ultrasonic machine. The changes that we noted in the liver were similar to those described by Bell (1957), except that no cavitation was produced in the viscera treated in vivo. The structures of the portal areas were less sensitive to ultrasound than the parenchymal cells.

Jankowiak et al. (1958) observed degenerative fatty infiltration in the livers of rats treated for 5-120 minutes with $1 \mathrm{watt} / \mathrm{sq} \mathrm{cm}$. No fatty infiltration was observed in the livers of animals in our experiments. The above authors attributed the hepatic changes to mechanical micromassage.

Severe degeneration and necrosis in the testes were produced by 3 watts $/ \mathrm{sq} \mathrm{cm}$ of ultrasound for 10-15 minutes underwater. Fragmentation and edema were seen in rats that received treatment of less intensity and shorter duration.

The formation of large multinucleated giant cells within the seminiferous tubules adjacent to the necrotic areas was a striking histologic feature. This appearance suggested the rupture of cell membranes within the tubules and the formation of syncytial masses of cytoplasm with aggregated nuclei. The epithelioid response to ruptured tubules of epididymis resembled that of spermatocytic granuloma. The nervous system is selectively heated by ultrasound and may lose its ability for conduction (Fry, 1953; Fry and Fry, 1953; Herrick and Krusen, 1954). This was undoubtedly the cause of paralysis of the hind legs of the rats.

Petechial hemorrhages were present in the intestine. Lehmann and Herrick (1953) feel that these are caused by "cavitation." The ulcers and necrosis, however, are very similar to the changes produced by heat and can be attributed to the thermal effect rather than to "cavitation." No cavitation was observed in the animals of our experiments. The hyaline droplet change in the proximal convoluted tubules of the kidney has not been previously reported in the literature. This change was unilateral, occurred only in animals that received abdominal irradiation, and was observed as early as 5 hours after treatment. There is little doubt that the change was a result of the ultrasound, but we cannot say if it was due to thermal or mechanical action, or both.

\section{SUMMARY}

Lesions can be produced in many different tissues with ultrasonic irradiation at intensities varying from 1 to 3 watts $/ \mathrm{sq} \mathrm{cm}$ for periods of 1 to 15 minutes. The higher the intensity and the longer the duration of treatment, the more severe were the lesions. Focused ultrasound waves of 37.5 total watts for 5 to 15 minutes produced localized areas of necrosis in liver.

Other histologic lesions produced by various intensities and durations of treatment included necrosis, inflammation and edema of skin, subcutaneum, and muscle; degeneration, necrosis and giant cell reaction in testis; necrosis, ulcers, inflammation and hemorrhage in the intestines; and necrosis of bone and hyaline droplet change in renal tubular epithelium.

Cavitation, probably due to the accumulation of bubbles of gas, was not observed in livers or other tissues of living animals that were treated. The change was produced in the livers of animals treated in situ after death and in livers removed from the body and treated.

\section{REFERENCES}

AldEs, J. H. (1957). Indications and contraindications for ultrasonic therapy in medicine. In "Ultrasound in Biology and Medicine" (E. Kelly, cd.), pp. 66-98. Williams and Wilkins, Baltimore, Maryland. 
Baldes, E. J., Herrick, J. F., and Stroebel, C. F. (1958). Biologic effects of ultrasound. Am. J. Phys. Med. 37, 111.

Bauer, A. W. (1951). Technique of ultrasonic therapy. Brit. J. Phys. Med. 14, 145.

Baum, G., and Greenwoud, I. (1960). Ultrasonography-an aid in orbital tumor diagnosis. A. M. A. Arch. Ophthal. 64, 180.

BELL, E. (1957). Some changes in liver tissue which survives irradiation with ultrasound. In "Ultrasound in Biology and Medicine" (E. Kelly, ed.), pp. 203-225. Williams and Wilkins, Baltimore, Maryland.

Bell, E. (1958). Action of ultrasound on adult and embryonic organ systems. Am. J. Phys. Med. 37, 184.

Carstensen, E. L. (1960). The mechanism of absorption of ultrasound in biological material. IRE (Inst. Radio Engr.) Trans. Med. Electron. 7, 158-162.

CHICK, B. B. (1957). Generating and measuring high-intensity ultrasound of frequencies between 1 and 68 megacycles. In "Ultrasound in Biology and Medicine" (E. Kelly, ed.), pp. 191-202. Williams and Wilkins, Baltimore, Maryland.

Crawforp, H. O., Wild, J. J., Wolf, P. I., and Fink, J. S. (1959). Transmission of ultrasound through living human thorax. IRE (Inst. Radio Engr.), Trans. Med. Electron. 6, 141-146.

Dimitrieva, N. P. (1960). Actions of ultrasonics on spontaneous and transplantable tumors of animals and on malignant tumors of humans. Probl. Oncol. (USSR) (English Transl.) 6, 1379.

Dunv, F. (1958). Physical mechanisms of the action of intense ultrasound on tissue. $A m$. $J$. Phys. Med. 37, 148.

Dussik, K. T. (1954), The ultrasonic field as a medical tool. Am. J. Phys. Med. 33, 5.

Fox, F. E., and Griffing, V. (1949). Experimental investigation of ultrasonic intensity gain in water duc to concave reflectors. J. Acoust. Soc. Am. 21, 352.

French, L. A., Wild, J. J., and Neal, D. (1951). Attempts to determine harmful effects of pulsed ultrasonic vibrations. Cancer 4, 342 .

FRY, F. J. (1958). Precision high intensity focusing ultrasonic machines for surgery. Am. J. Phys. Med. 37, 152.

Fry, W. J. (1953). Action of ultrasound on nerve tissue. J. Acous. Soc. Am. 25, 1.

FRY, W. J., AND FRY, R. B. (1953). Temperature changes produced in tissue during ultrasonic irradiation. J. Acous. Soc. Am. 25, 6.

FRY, W. J. (1955). Neurosonic surgery. In "Proceedings of the Fourth Annual Conference on Ultrasonic Therapy, Detroit" (D. Greenwood, ed.), pp. 41-46. The American Institute of Ultrasonics in Medicine.

FrY, W. J. (1957). Thermocouple probes. In "Ultrasound in Biology and Medicine" (E. Kelly, ed.), pp. 239-243. Williams and Wilkins, Baltimore, Maryland.

Fry, W. J. (1958a). Biological and medical acoustics. J. Acous. Soc. Am. 30, 387.

FrY, W. J. (1958b). Use of intense ultrasound in neurological research. Am.J. Phys. Med. 37, 143.

Gersten, J. W. (1954). Ultrasonics and muscle disease. Am. J. Phys. Med. 33, 68.

Herrick, J. F. (1953). Temperatures produced in tissues by ultrasound; experimental study using various technics. J. Acous. Soc. Am. 25, 12.

Herrick, J. F., and Krusen, F. H. (1954). Ultrasonics and medicine. IRE (Inst. Radio Engr.) Trans, Ultrasonics Eng. 1, 4-13.

Howry, D. H. (1957). Techniques used in ultrasonic visualization of soft tissues. In "Ultrasound in Biology and Medicine" (E. Kelly, ed.), pp. 49-65. Williams and Wilkins, Baltimore, Maryland. Hueter, T. F. (1958). Instrumentation for medical ultrasonics. Am. J. Phys. Med. 37, 222.

Jankowiak, J., Hasik, J., Majewski, Cz., and Markowski, R. (1958). Influence of ultrasound on some histological and histochemical reactions in the liver of the rat. Am.J. Phys. Med. $37,135$.

Jones, A. C. (1954). Clinical observations in the use of ultrasound. Am. J. Phys. Med. 33, 46.

KikUchi, Y., Uchida, A., Tanaka, K., and Wagai, T. (1957). Early cancer diagnosis through ultrasonics. J. Acous. Soc. Am. 29, 824.

KoвAK, D. (1954). Some physiologic considerations of the therapeutic action of ultrasonics. $A m$. J. Phys. Med. 33, 21. 
Lehmann, J. F., and Herrick, J. F. (1953). Biologic reactions to cavitation, a consideration for ultrasonic therapy. Arch. Phys. Med. Rehabil. 34, 86.

Lehmann, J. F. (1953a). The biophysical basis of biologic ultrasonic reactions with special reference to ultrasonic therapy. Arch. Phys. Med. Rehabil. 34, 139.

Lehmann, J. F. (1953b). The biophysical mode of action of biologic and therapeutic ultrasonic reactions. J. Acous. Soc. Am. 25, 17.

Ifesstf.r, M. A., and Matifernff, R. E. (1958). Fiffect of dental ultrasonics on lingual tissue and blood vessels. Am. J. Phys. Med. 37, 192.

Lynn, J. G., Zwemer, R. L., Chick, A. J., and Miller, A. E. (1942). A new method for the generation and use of focused ultrasound in experimental binlngy. J. Gen. Physiol. 26, 179.

Nyвorg, W. L. (1957). Physical aspects of high amplitude sound phenomena. In "Ultrasound in Biology and Medicine" (E. Kelly, ed.), pp. 15-29. Williams and Wilkins, Baltimore, Maryland.

OkA, M. (1958). Clinical use of ultrasonics and related biological research in Japan. Am. J. Phys. Med. 37, 210.

Schliephake, E. (1950). Supersonic and ultra-short waves. Brit. J. Phys. Med. 13, 145.

WiLd, J. J. (1950). The use of ultrasonic pulses for the measurement of biological tissues and the detection of tissue density changes. Surgery 27, 183.

Wild, J. J, and Neal, D. (1951). The use of high-frequency ultrasonic waves for detecting change of texture in living tissues. Lancet 1, 655 .

Wild, J. J., and ReID, J. M. (1953). The effects of biological tissues on 15 megacycle pulsed ultrasound. J. Acous. Soc. Am. 25, 270.

Wild, J. J., and Reid, J. M. (1954). Echographic visualization of lesions of the living intact human breast. Cancer Res. 14, 277.

Wild, J. J., and REID, J. M. (1955). Echographic tissue diagnosis. In "Proceedings of the Fourth Annual Conference on Ultrasonic Therapy, Detroit" (D. Greenwood, ed.), pp. 47-72. The American Institute of Ultrasonics in Medicine.

WILD, J. J, and REID, J. M. (1957). Progress in the techniques of soft tissue examination by 15MC pulsed ultrasound. In "Ultrasound in Biology and Medicine" (E. Kelly, ed.), pp. 30-48. Williams and Wilkins, Baltimore, Maryland.

Zinner, D. D. (1955). Ultrasonic studies in dentistry. In "Proceedings of the Fourth Annual Conference on Ultrasonic Therapy, Detroit" (D. Greenwood, ed.), pp. 6-16. The American Institute of Ultrasonics in Medicine. 